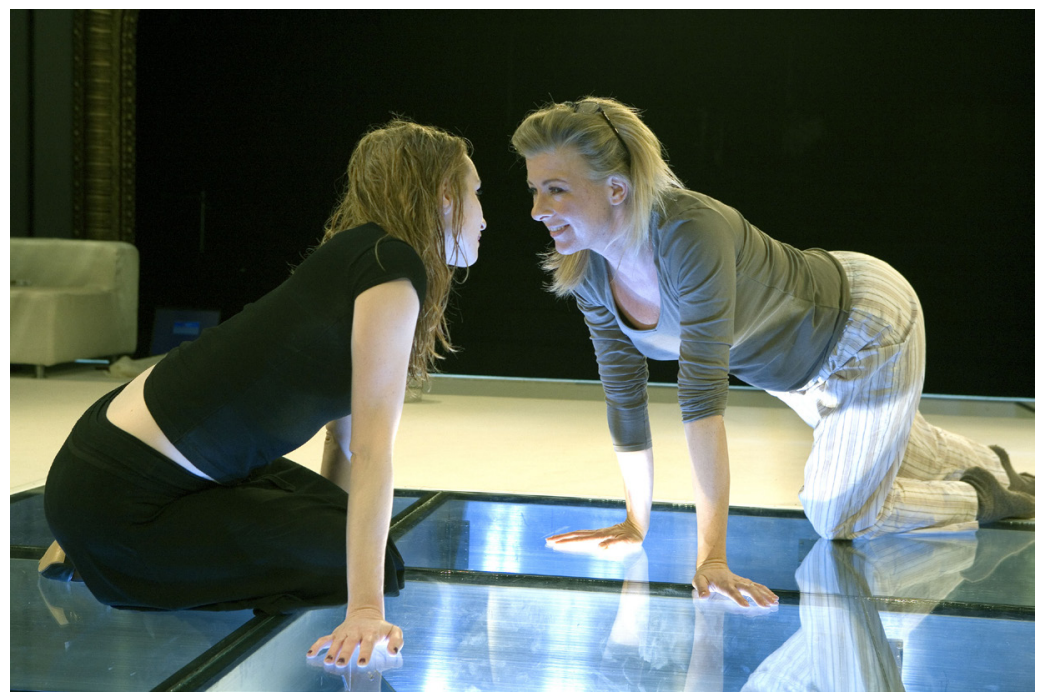

Hedda Gabler (Henrik Ibsen). Sonja Richter (Hedda) and Paprika Steen (Tesman). Betty Nansen Teatret, Copenhagen, 2005. Photographer: Thomas Petri. Copyright CC-BY-NC-ND: Thomas Petri, Betty Nansen Teatret, Copenhagen. 


\title{
7. AGAINST LOVE: Nora and Hedda on the Contemporary Scandinavian Stage
}

\author{
James Bond: “A woman!" \\ Holly Goodhead: "Your powers of observation do you \\ credit, Mr. Bond."
}

Moonraker, I979

The left-wing enthusiasm that swept through institutions of higher learning in the I960s was one of the most efficacious intellectual revolutions in recent history. ${ }^{\mathrm{I}}$ In Eros and Civilization, his most utopian book, Herbert Marcuse envisages a society where labor has been transformed into playful gratification and is accompanied by generalized sexual release. ${ }^{2}$ But as feminists have pointed out, such an underground portrayal of sexual liberation is arrogantly male: women are seen as "chicks" to be spread all over the print media, the younger and "softer" the better. ${ }^{3}$ This tradition is still alive in European theatre. Feminism has not been a dominant perspective in the works of celebrated German directors such as Frank Castorf and Thomas Ostermeier, to name only two. Neither of them appears to have been inspired by the Norwegian playwright Henrik Ibsen's liberating vision for women.

Hardly any other male dramatist has created as many major roles for women as Ibsen. However, many who have studied him tend to minimize his interest in gender. Joan Templeton examines this paradox in Ibsen's Women, and by emphasizing the gender issue in his plays, she reclaims him as a feminist author. ${ }^{4}$ Another recent writer on Ibsen, Toril Moi, analyzes how Ibsen relates to the modernist tradition, and argues against those who consider his work passé. 5 She sees two different forces as having generated

How to cite this book chapter:

Rosenberg, Tiina 2016. AGAINST LOVE: Nora and Hedda on the Contemporary Scandinavian Stage. In: Rosenberg, Tiina Don't Be Quiet, Start a Riot! Essays on Feminism and Performance. Pp. I 50-165. Stockholm: Stockholm University Press. DOI: http://dx.doi.org/Io.I6993/baf.g. License: CC-BY 4.0 
resistance to Ibsen. First, the mindset that is hostile to theatre and considers it unworthy in comparison to literature, and second, the demands that some working in contemporary theatre place on theatricality, while they reject drama-based theatre.

Moi's passionate defense of Ibsen may appear unnecessary in the Scandinavian countries, where he remains celebrated and his plays are constantly performed. The 2006 Ibsen festival in Oslo on the centenary of his death featured more than roo events, I 5 foreign performances, and 9 premieres at the National Theatre. Running for three weeks, the annual festival pays tribute to Ibsen in every way imaginable. Ibsen is the theatrical bridge between Norway and the rest of the world.

Ibsen's work has no need to be rescued or recast for our time. While it arises from a nineteenth-century sensibility, it foreshadows the spirit of modernity. Hedda, Nora, Hedvig, and Ibsen's other female characters show us how human beings - women in particular - relate to love, sexuality, class, and nuclear family obligations. They are eager to fulfill the expectations of others while remaining silent about the shortcomings and failures that surround them. Ibsen's dramaturgy easily lends itself to modern adaptations, just as his themes appear neither distant nor foreign to contemporary audiences.

Ibsen appears to be the foremost critic of romantic love in European drama. Such love and the ability to express "the right feelings" have primarily been associated with women. Ibsen's female characters challenge love, relationships, marriage, and the traditional heterosexual family, even if they do not do so in explicitly feminist terms. Nora Helmer and Hedda Gabler defy the norms and conventions that nineteenth-century bourgeois women are expected to observe. As Laura Kipnis has characterized it, they each break free from their "domestic gulag, one by abandoning her household, and the other by taking her life." ${ }^{6}$

Over the past century, Scandinavian theatre has gone from considering Nora and Hedda immoral to finally showing understanding for them both. They are no longer seen as anomalies on today's Nordic stages as they struggle with intimacy. Love for them is more than a bolt from the blue that defies all rational understanding. It is something they wish to see manifested in an egalitarian way that 
allows for co-existence. Productions of Ibsen's A Doll's House in Gothenburg, Sweden, in 2004, and Hedda Gabler in Copenhagen, Denmark, in 2006, show how Scandinavian intimacy is renegotiated in heterosexual and lesbian versions of the two plays.

\section{Henrik Ibsen, a feminist?}

Mainstream interpretations of Ibsen propose that he used the women's issue as a metaphor representing freedom for all humankind. The principal evidence for this is a speech Ibsen made on May 26, I 898, at a banquet in his honor given by the Norwegian Women's Rights League.

I am not a member of the Women's Rights League. Whatever I have written has been without any conscious thought of making propaganda. I have been more poet and less social philosopher than people generally seem inclined to believe. I thank you for the toast, but must disclaim the honor of having consciously worked for the women's rights movement. I am not even quite clear as to just what this women's rights movement really is. To me it has seemed a problem of humanity in general. ${ }^{7}$

Ibsen has a point: the "women's issue" does not concern women exclusively. It is part of the human condition. On the other hand, it would be naïve to pretend that the category of "woman" does not exist as a subaltern one.

The women in Ibsen's plays are very imposing. They shock by violating decorum and refusing to remain in their place according to the social mores of the time. They are not feminine in the sense of being "proper" mothers and sisters. They fire guns, abandon their homes, husbands, and children; in fact, they take over the masculine space in late nineteenth-century modern European realist drama. However, unlike Sweden's August Strindberg, Ibsen never fell into the essentialist and biological trap of the time. Late nineteenthcentury Europe was saturated with a new biologism that tried to explain differences between the sexes in scientific terms. Anatomy is our destiny, as Sigmund Freud has said, and women who refused to be wives and mothers were stigmatized as abnormal. In the prevailing view, women belonged to a problematic gender that constantly needed to be explained, guided, and controlled. 
Ibsen's insistence on women's autonomy makes him a modern dramatist of the first rank. He rejects the conventional dichotomy that divides femininity and masculinity into two completely different spheres. Ibsen's women are almost androgynous as they challenge the polarization of the sexes that is so much a part of patriarchal societies. While Ibsen's male characters fight to fulfill their masculinity, his female players struggle against their traditional gender script. As voices of modernity, they also come close to fulfilling the romantic ideals of women. Ibsen favors two types of women: one is sexually challenging, dangerous, and demanding, and the other is weak, friendly, and feminine, in short, paradigms of the bad and good woman.

\section{Renegotiating Nora}

A Doll's House, which premiered in I 879 , is usually considered the beginning of women's liberation in international drama and society as a whole in Europe and elsewhere. Within a decade after the play was written, it had been performed in almost every Western country, and its ideas about the infantilization of women after their marriage had provoked extensive discussion and analysis. When Nora climbs onto the kitchen table and dances the tarantella, exhibiting the flesh-colored stockings under her masquerade costume to her astounded husband, something irreversible changes in modern European drama.

A Doll's House was unique in that it examined the husband-wife relationship without invoking a love triangle. Instead, it focused on women's situation in the family power structure. Nora does not leave the house to take up a role in society. She is searching for those rooms of her own that her husband denied her. Society itself is her enemy, and the patriarchal family is its instrument. Nora has been toyed with, first by her father, then by her husband, as it she were a plaything. She has never been allowed to lead her own life.

A Doll's House unequivocally contradicts the notion of idealized, bourgeois Western love. Ann Swidler has analyzed the traditional love narrative as a mythical story with a specific content and function. ${ }^{8}$ Mythical love concerns the integrity of the individual; it constitutes a social drama in which individuals define themselves and their place in the world. This primarily involves a 
decisive choice. First, from out of a small circle of people, the one special person is sought. Love seems to be irrefutable, as unambiguous and true as the individual's own inner core, for it is by discovering whom you love that you discover who you really are. Second, true love must be as unique and exclusive as the individual. Third, as in Paul's letter to the Corinthians, love never fails, but endures and surmounts all obstacles, and may even continue beyond the individual's own existence.

Whether Nora's departure from her home is interpreted as a real or a metaphorical deed, it has been regarded over the decades as an immoral act. The "right" feeling (i.e., true love) not only places one in the correct position in the social hierarchy and gender order, but makes people congruous to one another. Through the enactment of the "right" feelings in the "right" way, people can establish themselves as the "right" kind of people. If so formulated, this "right" feeling appears as a form of social capital that confers the "right" social value and prestige on a person. In other words, the "right" feeling consists of something completely other than feelings. It is about conformity to social gender norms, which can only be transgressed at great cost. ${ }^{9}$

From the outset Nora has stood as a paradigm for a woman's liberation from a claustrophobic marriage. Her stage character once caused a sensation, and in a way it still does. Terje Maerli's 2004 adaptation of The Doll's House for the Gothenburg City Theatre was based on a vision of Nora as our contemporary. The production was less about women's liberation than about marriage as a social contract - even a "domestic gulag." In the space of two hours Maerli created a world not unlike that of Thomas Ostermeier's Nora at the Schaubühne in Berlin. We witness a busy, middle-class family using cell phones and laptops, always connected with other people, but never to those around them.

Maerli's Nora wears a red mini-skirt. Her sex appeal is very Lolita-like. The intense rhythm of the performance underlines the growing desperation in the doll's house before us. However, the ending takes a surprising turn. Just as Nora is about to leave, she appears before us properly dressed for the Scandinavian winter in boots and a warm coat. Ready to take on the world, she departs, but not without a sort of final reconciliation. Were this Strindberg, such a scene would have ended in total humiliation 
for the woman. Maerli, however, creates a situation in which the couple can say goodbye, if not as friends, at least on an almost equal basis. Still, this initial step toward equality only occurs after Torvald relinquishes ownership of the marriage and allows Nora her own choice.

Maerli's production focused on the possibility of an egalitarian outcome. Nora's leaving home is neither explained nor unexpected. Instead, it is the beginning of a new relationship in which the idea of an all-conquering and all-reconciling love has been exchanged for a more realistic awareness that coexistence requires constant compromise. Although such a mythic-romantic love story is rarely seen on the Scandinavian stage and belongs more to the Hollywood tradition, its allure is undeniable. The critique of romantic couples, marriage, and the nuclear family has been on the feminist agenda for a long time, but still has not managed to effectively challenge the hegemonic position of normative heterosexuality.

In the I970s, feminists declared that romantic love afflicted women in a double sense. It stood for an ideology that was repressive, holding women captive and exploiting them in heterosexual relationships. ${ }^{\circ}$ Love was an opiate for women, and it was thought that if only this false awareness were revealed it would die of itself. This did not happen. Maerli's production transposed the discussion to a more realistic, democratic, and equitable vision of love. According to Anthony Giddens, we are generally moving in the direction of a society with a new kind of democratic, equal intimate relationship at its core. This is a possibility open to everyone, since it is not based on compelling economic arrangements or social conventions. ${ }^{\text {II }}$

Giddens regards the women's liberation movement as one of the driving forces behind this development. However, it may be wishful thinking on his part. There is little evidence that people nowadays are engaged in a self-reflecting process of shaping themselves and their identity through love relationships. There is even less reason to assume that heterosexual relationships in the West or elsewhere are increasingly characterized by democratic love and intimacy. On the contrary, economic disparity and a lack of genuine equality continue to intrude into the everyday reality of intimate relationships. 
A more democratic version of the classic love story has emerged as a counterpart to previous ones. Echoing social changes and the evolution of new ideals, modern theatre is trying to keep up with contemporary intimacy by portraying it from different perspectives. The story line in the Gothenburg production of $A$ Doll's House does not tell us whether Nora and Helmer will find their way to a more equitable intimacy, but there is at least an opening for renegotiation of their heterosexual relationship. The problem appears to be that the tender aura of love may get thrown out with the divorce.

\section{"Good god! People don't do such things!"}

Hedda Gabler is the silent heroine who quietly walks into the next room and shoots herself. She does not say much in the play; she has few lines and not a single monologue. Nevertheless, her inner voice screams out to us throughout the drama. Her marriage to Jörgen Tesman is hateful to her, and what she craves more than her conventional life are horses and weapons. She is the proud daughter of General Gabler and as such is never referred to as "Hedda Tesman," her married name. To the end she remains Hedda Gabler, the general's daughter, rather than Tesman's wife. Whatever could have induced her to marry Tesman in the first place? Hedda's enigmatic answer is only, "I had finished dancing. My time was up!"

Although Hedda distains traditional women's activities in favor of masculine pursuits, the men in the play nevertheless treat her as a sexual object. Tesman steadfastly hold to the belief that Hedda is madly in love with him. Brack takes it for granted that she will be his mistress, and Lövborg cannot forgive her for not wanting to have sex with him. Although Hedda is pregnant, there is nothing maternal about her. She does not want to live for a man, but like a man. There seems to be some gender ambiguity here.

The prospect of having a child revolts her. She challenges the consensus of the bourgeoisie to which she belongs. It is not a coincidence that the final words in the play, "Good God! People don't do such things!" are spoken by a male observer. The male characters in Hedda Gabler are literally blind. Tesman does not 
even comprehend that Hedda is pregnant, thinking that their honeymoon has made her fat. Rainer Werner Fassbinder once said that women's attitudes and behavior say more about society than men's, since men often live as though everything is as it should be. ${ }^{12}$ This is certainly true of Jörgen Tesman.

If Hedda once seemed like a tragic impossibility, over the years she has come to symbolize how a patriarchal world refuses to share power. Hedda's burden is that she is expected to function as wife, childbearer, and hostess. But she is also General Gabler's daughter, a sophisticated woman who cannot suffer bourgeois bigotry. She rules mainly on the strength of her sexuality, flirting with everyone except her husband. Her primary target is Eilert Lövborg, a strong, intelligent man who has managed to overcome his alcoholism. But he refuses to be conquered by her and so must be crushed.

Hedda Gabler is Ibsen's reply to Strindberg's Miss Julie. Hedda, too, is a "man-woman," raised by her father and equipped with two pistols, often interpreted in the Freudian tradition as wielding a pair of threatening erections. She has also been read intertextually as a hysterical version of Mrs. Alving in Ghosts, a "frigid" woman who is incapable of having a heterosexual love relationship.

By not choosing to fall for any of the men around her, Hedda breaks the norm that Francesca Cancian calls the feminization of love. ${ }^{13}$ The term refers to a process that took place in the nineteenth century. In Europe it led to love being identified as an inner emotion. It was linked to the home and to those bourgeois women who were relegated to that sphere. It was bound up with descriptions of women requiring intimate tenderness, while men wanted sex. Women and men's lives are obviously more complex than that, but Cancian holds that these narratives encourage men to downplay, and women to exaggerate, their emotional needs. This, in turn, has served to undermine women's power, while maximizing the power of men.

Because Hedda breaks the heterosexual matrix, she has often been interpreted as a destructive character, a man-hating lesbian monster. Hedda's acute desperation rests on several elements: her impending role as a mother- which will chain her to her femininity; 
her way of using sex to manipulate and dominate men; and her upper-class origins. She can be called a disaster waiting to happen. In contrast to Thea Elvsted's “normal” femininity, Hedda's phallic non-femininity seems aggressive, hostile, and out of place. Thea, whose magnificent hair Hedda is constantly pulling, leaves the man she does not love for the one she does, something Hedda is not prepared to do. And so she must die!

The Western theatrical tradition seems to hold that the best woman on stage is a dead woman. A visit to the theatre is like going to one's own funeral, Hélène Cixous once wrote. ${ }^{\mathrm{I}}$ Western classical drama and opera celebrate women's death as a part of the pleasure of the total performance. Especially despicable women are sacrificed with great fanfare. The Western theatre as a whole perpetuates a social order that requires either domestication of the female protagonist or her death. ${ }^{\mathrm{I}}$

\section{Queering Hedda in Copenhagen}

"I always felt that Hedda Gabler was a terrible character," wrote the Swedish theatre critic Leif Zern in his review of the Stockholm City Theatre's production of Hedda Gabler in 2007. ${ }^{16}$ Hedda has just returned from her honeymoon and moved into her new home. Her husband, Jörgen Tesman, is in high spirits. He is on his way out the door to a gentlemen's dinner. When he returns he will work on his book about Flemish crafts of the Middle Ages. Meanwhile, Hedda is going mad. What kind of life is this? Hedda cannot cope with having to compromise, and Zern, the reviewer, wonders aloud why she married Tesman in the first place.

In another production of Hedda Gabler directed by Peter Langdal at the Betty Nansen Teatret in Copenhagen in 2006, Hedda marries a woman instead of a man. This innovative theatre has been exploring Ibsen for some time now. They staged a version of $A$ Doll's House that was expressive and violent, and their Peer Gynt was performed as a stand-up comedy act including rap music. In the case of Hedda Gabler their mise-en-scène was spectacular. The director used sexuality to investigate who is in love with whom and why. His approach was founded on a queer analysis that literally turned the play on its head: the stage was 
built above the auditorium, and the audience was seated around the Tesman's minimalist contemporary home, which resembled a boxing ring. Everything was hi-tech: laptops, cell phones, largescreen TV, air-conditioning - even the human relations seemed to be electronically controlled.

While the director made no major alterations in Ibsen's text, he did change the gender of the characters. He presents Hedda and Tesman as a young, newly-married lesbian couple. The roles were played by two prominent Danish actresses, Sonja Richter and Paprika Steen. Thea Elvsted, now also a male, is married to another man whom he wishes to leave in order to engage in a relationship with Lövborg, who turns out to be bisexual. As in Ibsen's original straight casting, the drama centers about the reunion of Hedda and Lövborg, despite the destructive love affair they once had.

Hedda, already bored with marriage, plays with her guns in a terrifying way, simulating a number of frightening death scenes. She suffers from a divided self that fluctuates between gay/ straight/bisexual inclinations, something she has tried to cover up by intensive engagement in sexual activities. Tesman, here a woman, does her best to keep things going. She is a modern, politically aware, intellectual lesbian who seeks social acceptance for her middle-class lesbian marriage, and who also desperately needs peaceful surroundings for her research and writing. She is so overeager in her quest for recognition and assimilation that she fails to recognize Hedda's frustration and existential angst. The lesbian couple is also threatened by the aggressive masculinity of Brack, the lawyer, who expresses his deep-rooted lesbophobia when drunk. Brack seems to suggest there is room for a "real" man in this lesbian thing, a fairly common attitude towards lesbians.

Langdal's production not only breaks with the heteronormative tradition of Hedda Gabler interpretations, but also demonstrates that not everyone is able to cope with instabilities, a code word for modern urban lifestyles. The portrayal of the protagonists as a lesbian couple also highlights heterosexual love as the culturally and socially dominant matrix that organizes the way relationships are supposed to be initiated, conducted, and experienced in order to be comprehensible to the characters and to society in general. 
There have been few cultural representations of non-heterosexual love in films, on stage, and in novels, since relationships are usually structured upon heterosexuality, although modeling on samesex relationships is increasing. However, Langdal's transposition of Hedda Gabler from heterosexuality to homosexuality does not necessarily mean that the heterosexual matrix has been broken. ${ }^{17}$

Langdal's production was probably not so ambitious as to challenge the heterosexual matrix that is also actively at work in same-sex relationships. Hedda is unhappy regardless of whether she is a lesbian or a heterosexual woman. While her partner is preoccupied with forging political alliances and the democratic acceptance of lesbian relationships in the world around her, Hedda could not care less. She takes no interest in having their relationship appear "good" and acceptable in the eyes of society, and she seems even less interested in the sexual politics that have broadened to include same-sex couples in Scandinavia.

Inclusion, however, comes at a price. Apart from the practical challenges of creating intimacy, lesbian and gay male couples still live in a society dominated by homophobia. The heterosexual matrix that shapes the love narratives and ideals of intimacy today is just as exclusionary and normative as before. Only respectable same-sex twosome relationships are acceptable in the public eye. Hedda's sexual dissatisfaction, appropriated from Ibsen's heterosexual version, is now carried over to the lesbian relationship. In this case, however, it is no salvation and leads to a renegotiation of the intimacy that defines sexual relationships, regardless of orientation.

Hedda Gabler in Copenhagen renews the discussion of emotion in Ibsen's work. Emotions have long been considered the hardest part of human personality to control, and for that reason the truest and most universally valid. The idea that emotions are exponents of truth is a contemporary Western belief. It views the individual as a unique being whose emotions are thought to communicate the inner core of one's being.

It may be very difficult to identify a feeling if we do not already know what it feels like and how it should be expressed. Like other emotions, love cannot thrive in isolation: it is a social and cultural construct. Michelle Rosaldo has written that emotions 
are "embodied thoughts." They are culturally specific, social practices, organized by narratives that we both enact and retell, and which shape and are shaped by our experiences. ${ }^{18}$

\section{Focus on emotions}

No matter how we interpret A Doll's House or Hedda Gabler, it is clear that frustration is crushing Nora and Hedda. Both characters convince us that something is fundamentally wrong with the world. Recent Scandinavian presentations of these two dramas have consequently challenged the structures that shape the emotional life of the individual. Hedda Gabler, who has existed for over a century as a destructive - although seductive - femme fatale, is no longer portrayed in that way, and has not been for many years. In our times, when divorce is the rule rather than the exception, Nora no longer strikes us as an anomaly, but as rather commonplace. Ibsen's ordinariness continues to appeal to Scandinavian audiences. In his day and in ours he reveals fundamental social injustices that society faces the lack of sexual equality being just one example.

In The Cultural Politics of Emotion, Sara Ahmed reminds us that injustice is also a question of how bodies come into contact with other bodies. We need to respond to injustice in a way that shows the complexity of the relation between violence, power, and emotion, rather than denying it. ${ }^{19}$ If injustice is not simply about feeling bad, then justice is not only a matter of feeling good, overcoming pain, or even achieving happiness since being happy is not in itself a sign of justice. No one can be promised happiness as a return on their investment in social norms. Lauren Berlant considers this fantasy of happiness an ignorant form of optimism that believes "adjustment to certain forms or practices of living and thinking will secure one's happiness." ${ }^{20}$ Such optimism does not originate from a subject, but is generated by promises made to the subject, which then may circulate as "truths" in public culture. ${ }^{21}$

Martin Heidegger has given a systematic account of how emotions influence our relationship to the world in $\mathbb{S} 29$ of Sein und Zeit. He calls emotions Befindlichkeit, our way of existing in body and world in a way that makes life relevant to us. Without 
emotion, Heidegger says, there is no will, no thought, and no meaningful world in which to act. Emotions are not superficial attributes; they are the foundation of our interrelations with other human beings. ${ }^{22}$

The emotions and love relationships that Ibsen portrays are inextricably bound up with social structures and power constellations beyond the individual. Those structures intersect and diverge in a nexus of gender, sexuality, class, race, and other power axes. One factor that seems to have disappeared from the emotional agenda of representation, however, is the dream of an all-consuming and all-conquering romantic love that Ibsen has so effectively deflated. Still, the dream is probably stronger than reality, and thus may persist in the imagination. As Laura Kipnis writes in Against Love: "Who would dream of being against love? No one. Love is, as everyone knows, a mysterious and all-controlling force, with vast power over our thoughts and life decisions. Love is boss, and a demanding one too: it demands our loyalty. ... There's no way of being against love precisely because we moderns are constituted as beings yearning to be filled, craving connection, needing to adore and be adored, because love is vital plasma and everything else in the world is just tap water." ${ }^{23}$

\section{Notes}

I. Scruton, Thinkers, I, 87.

2. Segal, Straight Sex, I7.

3. Ibid., 22.

4. Templeton, Ibsen's Women.

5. Moi, Henrik Ibsen.

6. Kipnis, Against Love, 52-104.

7. Finney, "Ibsen and Feminism," 90.

8. Swidler, Talk of Love.

9. Nordin, Man ska ju vara två, 57-60.

Io. Jackson, Heterosexuality in Question; Pearce \& Stacey, Romance Revisited. 
I I. Giddens, Transformation of Intimacy, I 28.

I2. Bensoussan, "Wir sitzen auf einem Vulkan," 570.

I3. Cancian, "Feminization of Love."

I4. Cixous, "Aller à la mer."

I 5 . Clément, L’opéra.

I6. Zern, "Magisk Hedda."

I7. The heterosexual matrix is defined by Judith Butler as "a hegemonic discursive/epistemic model of gender intelligibility that assumes that for bodies to cohere and make sense there must be a stable sex expressed through a stable gender (masculine expresses male, feminine female) that is oppositionally and hierarchically defined through the compulsory practice of heterosexuality." Gender Trouble, I 5 I, note 6.

I 8. Nordin, Man ska ju vara två, 58-59; Rosaldo, "Anthropology of Self."

I9. Ahmed, Cultural Politics, I96.

20. Berlant, “Two Girls,” 75.

21. Ahmed, Cultural Politics, 196.

22. Martin Heidegger, Sein und Zeit.

23. Kipnis, Against Love, 3.

\section{Works Cited}

Ahmed, Sara. The Cultural Politics of Emotion. New York: Routledge, 2004 .

Bensoussan, Georges. "Wir sitzen auf einem Vulkan: Rainer Werner Fassbinder über Deutschland,Antisemitismus und Homosexualität." In Fassbinder über Fassbinder: Die ungekürzten Interviews, edited by Robert Fischer, 557-578. Frankfurt: Verlag der Autoren, 2004.

Berlant, Laurent. “Two Girls, Fat and Thin.” In Regarding Sedgwick: Essays on Queer Culture and Critical Theory, edited by Stephen Barber and David Clark, 7 I-I08. New York: Routledge, 2002.

Butler, Judith. Gender Trouble: Feminism and the Subversion of Identity. New York: Routledge, I990. 
Cancian, Francesca M. "The Feminization of Love." Signs: Journal of Women in Culture and Society I I (1986): 692-709.

Cixous, Hélène, “Aller à la mer.” Le Monde, 28 April 1977.

Clément, Catherine. L'opéra ou la défaite des femmes. Paris: Grasset, I979.

Finney, Gail. "Ibsen and Feminism.” In The Cambridge Companion to Ibsen, edited by James McFarlane, 89-I05. Cambridge, UK: Cambridge University Press, I994.

Giddens, Anthony. The Transformation of Intimacy. Oxford: Polity Press, I992.

Heidegger, Martin. Sein und Zeit, Tübingen: Niemeyer, 2006 [1927]. Jackson, Stevi. Heterosexuality in Question. London: Sage, I999.

Kipnis, Laura. Against Love: A Polemic. New York: Pantheon, 2003. Moi, Toril. Henrik Ibsen and the Birth of Modernism: Art, Theatre, Philosophy. Oxford: Oxford University Press, 2006.

Nordin, Lissa. Man ska ju vara två: Män och kärlekslängtan i norrländsk glesbygd (Two Is Better than One. Men, Love, and Longing in Northern Rural Areas). Stockholm: Natur och Kultur, 2007.

Pearce, Lynne, and Jackie Stacey, eds. Romance Revisited. London: Lawrence \& Wishart, I995.

Rosaldo, Michelle Z. "Toward an Anthropology of Self and Feeling." In Culture Theory: Essays on Mind, Self, and Emotion, edited by Richard A. Shweder and Robert A. Levine, I37-I 57. Cambridge: Cambridge University Press, I984.

Scruton, Roger. Thinkers of the New Left. London: Longman, I98 5.

Segal, Lynne. Straight Sex: The Politics of Pleasure. London: Virago Press, I994.

Swidler, Ann. Talk of Love: How Culture Matters. Chicago: University of Chicago Press, $200 \mathrm{I}$.

Templeton, Joan. Ibsen's Women. Cambridge: Cambridge University Press, I997.

Zern, Leif. “Magisk Hedda.” Dagens Nyheter, 2 I April 2007. 